\title{
Spectrophotometric Determination of Palladium by the Colouration with 2-(2-Quinolylazo)-5-diethylaminobenzoic Acid
}

\author{
Zhangjie Huang, Qunyan Wei, Xiangjun Yang, Qiufen Hu, ${ }^{\dagger}$ Jing Chen, and Guangyu Yang* \\ Department of Chemistry, Yunnan University, Kunming, 650091, P.R. China. *E-mail: gyyang@cyats.com \\ 'Department of Chemistry, Yuxi Teacher's College, Yuxi 653100, P.R. China \\ Received January 19, 2005
}

Key Words : 2-(2-Quinolylazo)-5-diethylaminobenzoic acid, Palladium, Spectrophotometry

Palladium has been used in various ways as a hydrogenation catalyst, microcontactors in the electronics, hard alloy in dentistry and in the last few years as a component in the three-way catalysts in automobile exhaust catalytic beads. Due to the introduction of palladium, platinum and rhodium for use in catalytic converters in motor vehicles, the emission of these metals into the environment has increased. In addition, an increased uptake of palladium by plants has led to soil pollution. Palladium is thought to be one of the strongest allergens from a health hazard viewpoint. ${ }^{1,2}$ For these reasons, establishing rapid and accurate methods for the determination of palladium for industrial process, quality and pollution control is important. Many sensitive methods, such as spectrofluorimetry, X-ray fluorescence spectrometry, neutron activation analysis, atomic absorption spectrometry have widely been used for the determination of palladium. However, spectrophotometric methods have gained popularity for palladium determination as advantageous in respect of simplicity and low operating costs. A wide variety of spectrophotometric reagents, such as azo dyes, rhodanine derivatives, porphyrin ligands, thiourea derivatives, 8aminoquinoline derivatives and nitroso dye have been developed for the determination of palladium. ${ }^{3-12}$

In our previous work, some 2-quinolylazo reagents were reported for the determination of metal ions. ${ }^{13-16}$ These reagents have a higher sensitivity than that of pyridylazo reagents because of its larger conjugated system. However, the use of these reagents for the determination of palladium has not been reported yet. We had synthesized 2-(2quinolylazo)-5-diethylaminobenzoic acid (QADEAB) and used it to the determination of cobalt. ${ }^{17}$ This reagent has high sensitivity. In this paper, we thoroughly studied the color reaction of QADEAB with palladium. The results show that QADEAB is a highly sensitive, selective and convenience reagent for palladium. Based on this, a highly sensitive, selective and convenient method for the determination of palladium in water and catalyst was developed.

\section{Experimental Section}

Experimental Apparatus. A UV-160-A spectrophotometer (Shimadzu Corporation, Tokyo, Japanese) equipped with $1 \mathrm{~cm}$ cells was used for all absorbance measurements. $\mathrm{pH}$ values was determined with a Beckman $\Phi-200 \mathrm{pH}$ meter
(Beckman Instruments, Fullerton, CA, USA).

Synthesis of QADEAB. QADEAB was synthesized according to the our previous proposed procedure: ${ }^{17} 7.2 \mathrm{~g}$ of 2-aminoquinoline was dissolved in $300 \mathrm{~mL}$ of anhydrous ethanol and $2.2 \mathrm{~g}$ of sodamide were added. The mixture was refluxed for $6 \mathrm{~h}$ in a boiling water bath. Hereafter, $8.5 \mathrm{~mL}$ of isoamyl nitrite were added. The mixture was again refluxed for $40 \mathrm{~min}$ in a boiling water bath. Then the solution was cooled and kept over night at $0{ }^{\circ} \mathrm{C}$. Diazo salt was obtained with a yield of $93 \%$. The diazo salt was then dissolved in $200 \mathrm{~mL}$ of anhydrous ethanol, m-diethylaminobenzoic acid (8.0 g) was added, and carbon dioxide was passed through the stirred solution until $\mathrm{pH}$ reached the value of about 8.0. Finally ethanol was evaporated and the residue was recrystallized in $35 \%$ ethanol. QADEAB was obtained with a yield of $21 \%$; mp. $241-243{ }^{\circ} \mathrm{C}$. The structure of QADEAB is show in Figure 1.

Reagents. All of the solutions were prepared with ultrapure water obtained from a Milli-Q50 SP Reagent Water System (Millipore Corporation, USA). A $5 \times 10^{-4} \mathrm{~mol} \mathrm{~L}^{-1}$ of QADEAB solution was prepared by dissolving QADEAB with $95 \%$ of ethanol. A stock standard solution of palladium (1.0 $\mathrm{mg} \mathrm{mL}^{-1}$ ) was obtained from Chinese Standard Center, and a working solution of $2.0 \mu \mathrm{g} \mathrm{mL} \mathrm{m}^{-1}$ was prepared by diluting this solution. A $5 \mathrm{~mol} \mathrm{~L}^{-1}$ of hydrochloric acid was used. Cetyl trimethylammonium bromide (CTMAB) solution $(1.0 \%(\mathrm{w} / \mathrm{v}))$ was prepared by dissolving CTMAB with $20 \%$ ethanol. All chemicals used were of analytical grade unless otherwise stated.

The river water for determination was collected from Panglog River, Kunming, P. R. China according to literature. ${ }^{18}$ The Plating Effluents for determination were collected from Yunnan Smelt Factory, Kunming, P. R. China according to literature ${ }^{18}$ too. The catalyst for determination is a Chinese Certified Reference Standard Material (GBW(E)070029) obtained from Chinese Standard Material Centre. The certified standard palladium value is $(0.538 \pm$

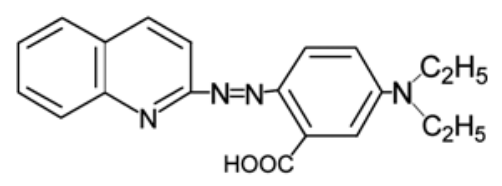

Figure 1. The structure of QADEAB. 
$0.005) \%$.

General Procedure. To a standard or sample solution containing no more than $15 \mu \mathrm{g}$ of $\mathrm{Pd}(\mathrm{II})$ in a $25 \mathrm{~mL}$ of calibrated flask, $5 \mathrm{~mL}$ of $5 \mathrm{~mol} \mathrm{~L}^{-1}$ hydrochloric acid, 4.0 $\mathrm{mL}$ of $5 \times 10^{-4} \mathrm{~mol} \mathrm{~L}^{-1} \mathrm{QADEAB}$ solution and $2.0 \mathrm{~mL}$ of $1.0 \%$ CTMAB solution were added. The mixture was diluted to volume of $25 \mathrm{~mL}$ and mixed well. After $10 \mathrm{~min}$, the absorbance was measured in a $1 \mathrm{~cm}$ cell at $625 \mathrm{~nm}$ against a reagent blank prepared in a similar way without palladium.

\section{Results and Discussion}

Absorption Spectra. The absorption spectra of QADEAB and its $\mathrm{Pd}(\mathrm{II})$ complex are shown in Figure 2. The absorption peaks of QADEAB and its complex are located at $460 \mathrm{~nm}$ and $625 \mathrm{~nm}$, respectively. The isosbestic point is $551 \mathrm{~nm}$.

Effect of Acidity. Results showed that the optimal condition for the reaction of $\mathrm{Pd}(\mathrm{II})$ with QADEAB is in the acid medium. Therefore, the effect of hydrochloric acid, sulfuric acid, perchloric acid, phosphoric acid on the color reaction of $\mathrm{Pd}(\mathrm{II})$ with QADEAB was studied. The experiment shows that hydrochloric acid has the best effect, and the concentration of hydrochloric acid within $0.5-2.5$ mol $\mathrm{L}^{-1}$ was found to give a maximum and constant absorbance. So $5 \mathrm{~mL}$ of $5 \mathrm{~mol} \mathrm{~L}^{-1}$ of hydrochloric acid was recommended.

Effect of Surfactants. The effects of surfactants on Pd(II)-QADEAB system were studied. The results (Table 1)

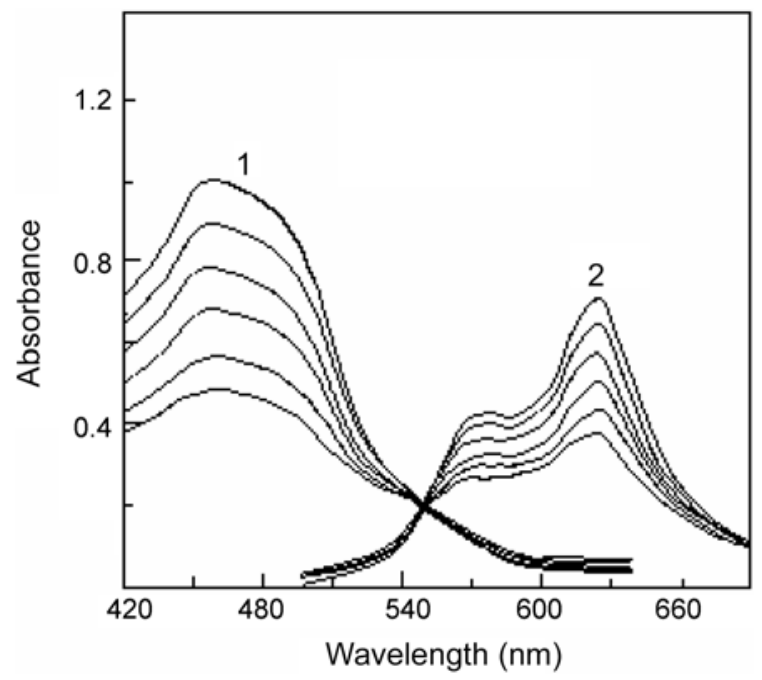

Figure 2. Absorption spectra of QADEAB and its Pd(II) complex. 1: QADEAB-CTMAB blank against water, 2: QADEAB-Pd(II)CTMAB complex against reagent blank. showed that without surfactants existing, or in anionic surfactants medium, the Pd(II)-QADEAB chromogenic system give a low absorption, whereas in the presence of nonionic surfactants or cationic surfactants medium, the absorption of the chromogenic system increases markedly. CTMAB is the best additive. The use $1-4 \mathrm{~mL}$ of $1.0 \%$ CTMAB solution give a constant and maximum absorbance. Accordingly, the use of $2 \mathrm{~mL}$ was recommended.

Effect of QADEAB Concentration. For up to $15 \mu \mathrm{g}$ of Pd(II), the use of about $3.5-5 \mathrm{~mL}$ of $5 \times 10^{-4} \mathrm{~mol} \mathrm{~L}^{-1}$ of QADEAB solution has been found to be sufficient for a complete reaction. Accordingly, $4 \mathrm{~mL}$ of QADEAB solution was added in all further measurement.

Stability of the Chromogenic System. After mixing the components, the absorbance reaches its maximum within 8 min at room temperature and remains stable for at least $6 \mathrm{~h}$ in aqueous solution.

Calibration Curve and Sensitivity. The calibration curve show that Beer's law is obeyed in the concentration range of 0.01-0.6 $\mu \mathrm{g} \mathrm{Pd}(\mathrm{II})$ per $\mathrm{mL}$, The linear regression equation obtained was: $A=1.421 C\left(\mu \mathrm{g} \mathrm{mL}^{-1}\right)+0.0167,(r=0.9995)$. The molar absorptivity was calculated to be $1.51 \times 10^{5}$ $\mathrm{L} \cdot \mathrm{mol}^{-1} \cdot \mathrm{cm}^{-1}$ at $625 \mathrm{~nm}$. The relative standard deviation for the slope of the calibration curve (11 repeat times) was $0.75 \%$. The detection limit, based on the three times of the relative standard deviation of the blank, is $1.2 \mu \mathrm{g} \mathrm{L} \mathrm{L}^{-1}$.

Composition of the Complex. The composition of the complex was determined by continuous variation (Figure 3 ) and molar ratio method (Figure 4). Both showed that the molar ratio of $\mathrm{Pd}(\mathrm{II})$ to $\mathrm{QADEAB}$ is $1: 2$.

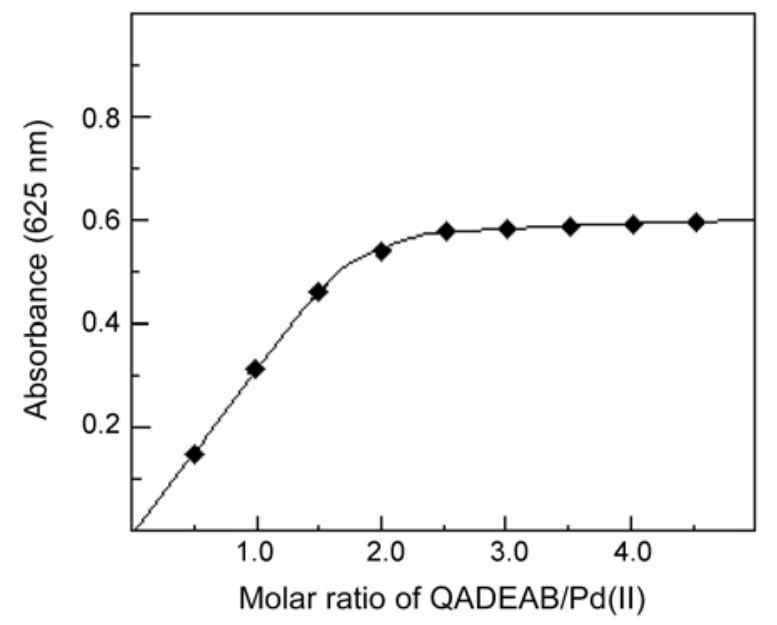

Figure 3. Composition of Pd(II)-QADEAB complex by molar ratio method. The concentration $\mathrm{Pd}$ (II) was $0.40 \times 10^{5} \mathrm{~mol} \mathrm{~L}^{-1}$, other conditions as standard procedure

Table 1. The Effect of surfactants on Pd(II)-QADEAB chromogenic system.

\begin{tabular}{ccccccccc}
\hline Surfactant & Absence & Emulsifier-OP & Tween-80 & Tween-20 & Tween-60 & SDS & CTMAB & CPB \\
\hline$\lambda \max (\mathrm{nm})$ & 590 & 610 & 615 & 615 & 615 & 595 & 625 & 620 \\
$\varepsilon\left(\times 10^{4}\right)$ & 9.92 & 12.5 & 12.8 & 13.2 & 13.6 & 7.23 & 15.1 & 14.2 \\
$\mathrm{~L} \cdot \mathrm{mol}^{-1} \cdot \mathrm{cm}^{-1}$ & & & & & & & & \\
\hline
\end{tabular}




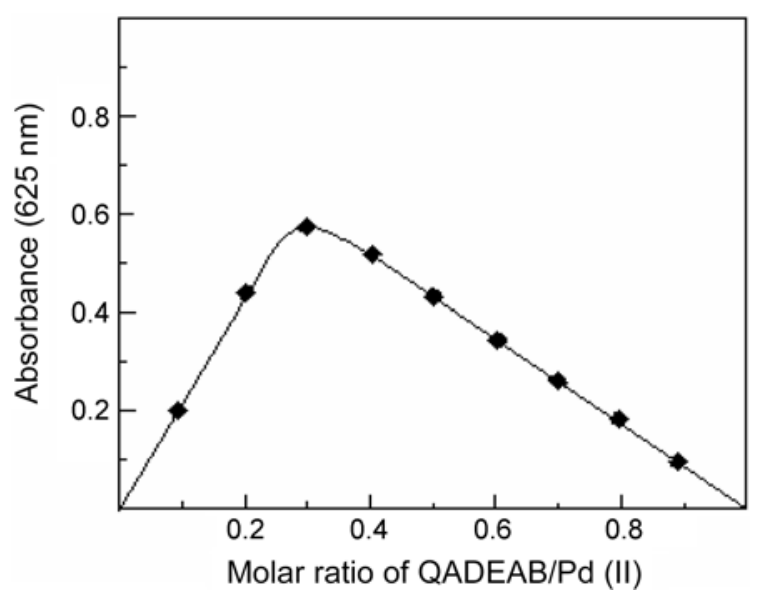

Figure 4. Composition of $\mathrm{Pd}(\mathrm{II})-\mathrm{QADEAB}$ complex by continuous variation method. The concentration of Pd(II)+QADEAB was $1.5 \times 10^{5} \mathrm{~mol} \mathrm{~L}^{-1}$, other conditions as in standard procedure

Table 2. Tolerance limits for the determination of $5 \mu \mathrm{g}$ of $\mathrm{Pd}(\mathrm{II})$ with QADEAB (relative error $\pm 5 \%$ ).

\begin{tabular}{lc}
\hline Ion added & Tolerate $(\mathrm{mg})$ \\
\hline $\mathrm{NO}_{3}{ }^{-}, \mathrm{K}^{+}$, borate, $\mathrm{Na}, \mathrm{Cl}^{-}, \mathrm{Mg}^{2+}, \mathrm{SO}_{4}{ }^{2-}, \mathrm{ClO}_{4}^{-}$ & 200 \\
$\mathrm{Li}^{+}, \mathrm{Al}^{3+}, \mathrm{PO}_{4}{ }^{3-}, \mathrm{NO}_{2}{ }^{-}, \mathrm{ClO}_{3}{ }^{-}$ & 20 \\
$\mathrm{Ca}^{2+}, \mathrm{Sr}^{2+}, \mathrm{IO}_{3}{ }^{-}, \mathrm{BrO}_{3}{ }^{-}, \mathrm{B}(\mathrm{III})$ & 10 \\
$\mathrm{Mn}^{2+}, \mathrm{Ce}(\mathrm{IV}), \mathrm{Fe}^{3+}, \mathrm{Mo}(\mathrm{VI}), \mathrm{V}(\mathrm{V})$ & 5 \\
$\mathrm{Ti}(\mathrm{IV}), \mathrm{Bi}(\mathrm{III}), \mathrm{Cr}\left(\mathrm{VI}^{2}\right), \mathrm{Ba}^{2+}, \mathrm{W}(\mathrm{WI}), \mathrm{U}(\mathrm{IV}),\left[\mathrm{Co}^{2+}\right]^{*}$ & 1 \\
$\mathrm{Cd}^{2+}, \mathrm{Pd}^{2+}, \mathrm{Cr}^{3+}, \mathrm{La}^{3+}, \mathrm{Zn}^{2+}, \mathrm{Zr}(\mathrm{IV}),\left[\mathrm{Ni}{ }^{2+}\right]^{*}$ & 0.5 \\
$\mathrm{Bi}(\mathrm{III}), \mathrm{Pb}{ }^{2+}, \mathrm{Hg}^{2+}, \mathrm{Sb}^{3+}, \mathrm{Th}(\mathrm{IV}), \mathrm{Sn}(\mathrm{IV})$ & 0.1 \\
$\mathrm{Se}(\mathrm{IV}), \mathrm{Te}(\mathrm{IV}), \mathrm{Au}^{3+}, \mathrm{Cu}^{2+}, \mathrm{Ag}^{+}$ & 0.05 \\
$\mathrm{Ni}^{2+}, \mathrm{Co}^{2+}$ & 0.01 \\
\hline
\end{tabular}

*masked with $2 \mathrm{~mL}$ of $10 \%$ citric acid
Interference. The selectivity of the proposed method was investigated by the determination $5 \mu \mathrm{g} 25 \mathrm{~mL}^{-1}$ of $\mathrm{Pd}$ (II) in the presence of various ions within a relative error of $\pm 5 \%$. The results are given in Table 2 . The results shows that the $\mathrm{Ni}$ (II) and $\mathrm{Co}$ (II) have a low tolerance limits. However, the $\mathrm{Ni}$ (II) and $\mathrm{Co}$ (II) can be masked with citric acid. The tolerance limits reaches $1 \mathrm{mg}$ for $\mathrm{Co}$ (II) and $0.5 \mathrm{mg}$ for $\mathrm{Ni}(\mathrm{II})$ when asked with citric acid. This method has high selectivity.

Application. The proposed method has been successfully applied to the determination of palladium in water and catalyst.

For water sample, taking an appropriate volume (plating effluents $20 \mathrm{~mL}$, river water $500 \mathrm{~mL}$ ) of water sample in a $500 \mathrm{~mL}$ flask. The samples were concentrated to about 10 $\mathrm{mL}$ by heating on a hot plate. $5 \mathrm{~mL}$ concentrated nitric acid and $2 \mathrm{~mL}$ of $30 \%$ hydrogen peroxide were added in this solution. The mixture was heated on a hot plate and evaporated to near dryness. The residue was dissolved with $5 \mathrm{~mL}$ of $5 \%$ hydrochloric acid and transferred into a calibrated flask. $2 \mathrm{~mL}$ of $10 \%$ citric acid was added to mask the nickel and cobalt, and the solution was neutralized with sodium hydroxide. The palladium content was analyzed by general procedure. The recovery test of palladium was determined by adding $1.0 \mu \mathrm{g}$ of palladium to water samples. A standard method using flame atomic absorption spectrometry together with preconcentration as literature ${ }^{19}$ was also used as reference method. The results are shown in Table 3.

For catalyst, $0.1 \mathrm{~g}$ of samples was weighted accurately into the Teflon high-pressure microwave acid-digestion bomb (Fei Yue, Analytical Instrument Factory, Shanghai, China). $3.0 \mathrm{~mL}$ of concentrated nitric acid, $2 \mathrm{~mL}$ of hydro-

Table 3. Determination of palladium in the water and catalyst samples.

\begin{tabular}{ccccc}
\hline Samples & AAS method & Found & RSD\% $(\mathrm{n}=5)$ & Recovery $(\%)(\mathrm{n}=5)$ \\
\hline River water & $\left.0.0285(\mu \mathrm{g} \mathrm{mL})^{-1}\right)$ & $0.0274\left(\mu \mathrm{gL}^{-1}\right)$ & 2.6 & 93 \\
Plating effluents & $0.278\left(\mu \mathrm{g} \mathrm{mL}^{-1}\right)$ & $0.285\left(\mu \mathrm{gL} \mathrm{m}^{-1}\right)$ & 2.2 & 96 \\
Catalyst & $0.544(\%)$ & $0.541(\%)$ & 1.4 & 102 \\
\hline
\end{tabular}

Table 4. Comparison of reagents for spectrophotometric determination of palladium.

\begin{tabular}{|c|c|c|c|c|c|}
\hline Reagent & Medium/Solvent & $\begin{array}{c}\lambda \max \\
(\mathrm{nm})\end{array}$ & $\begin{array}{c}\varepsilon\left(\times 10^{4}\right) \\
\mathrm{L} \cdot \mathrm{mol}^{-1} \cdot \mathrm{cm}^{-1}\end{array}$ & $\begin{array}{c}\text { Linear Range } \\
(\mu \mathrm{g} / \mathrm{mL})\end{array}$ & Ref \\
\hline 5-(5-Nitro-2-pyridylazo)-2,4-diaminotoluene & In hydrochloric acid medium & 592 & 1.9 & $0-0.9$ & 4 \\
\hline$o$-Hydroxyacetophenone thiosemicarbazone & In aqueous at $\mathrm{pH} 6.0$ & 370 & 0.90 & $0.42-10.6$ & 5 \\
\hline 1-(2-Pyridylazo)-2-naphthol & By solid-liquid extraction at $90^{\circ} \mathrm{C}$ & 678 & 1.2 & $0.1-1.8$ & 6 \\
\hline $\begin{array}{l}\text { 2-(5-Nitro-2-pyridylazo)-5-(N-propyl-N-3- } \\
\text { sulfopropylamino)-phenol }\end{array}$ & In weak acidic media & 612 & 10.8 & $0-2.5$ & 7 \\
\hline $\begin{array}{l}\text { N-Dodecyl-N'-(sodium p-amino- } \\
\text { benzenesulfonate)-thiourea }\end{array}$ & $\begin{array}{l}\text { In the presence of CTMAB and } \\
\text { NaAc-HAc buffer solution }\end{array}$ & 296 & 7.41 & $0-0.5$ & 8 \\
\hline Pyridoxal-4-phenyl-3-thiosemicarbazone & Extracted into benzene at $\mathrm{pH} 3.0$ & 460 & 2.20 & $0.4-6.4$ & 9 \\
\hline 2,2'-Dithiodianilline & $\begin{array}{l}\text { Extraction of isobutyl methyl ketone at } \\
\text { pH } 3\end{array}$ & 397 & 14.7 & $0.003-0.2$ & 10 \\
\hline $\begin{array}{l}\text { 2-(2-Quinolinylazo)-5-diethylaminobenzoic } \\
\text { acid }\end{array}$ & $\begin{array}{l}0.5-2.5 \mathrm{~mol} \mathrm{~L}^{-1} \text { of } \mathrm{HCl} \text { and } \mathrm{CTMAB} \\
\text { medium }\end{array}$ & 625 & 15.1 & $0.01-0.6$ & $\begin{array}{l}\text { This } \\
\text { work }\end{array}$ \\
\hline
\end{tabular}


chloric acid and $5.0 \mathrm{~mL}$ of $30 \%$ hydrogen peroxide were added. The bombs were sealed tightly and then positioned in the carousel of the microwave oven (Model WL 5001, 1000 W, Fei Yue Analytical Instrument Factory, Shanghai, China). The system was operated at full power for $10 \mathrm{~min}$. The digest was evaporated to near dryness. The residue was dissolved with $10 \mathrm{~mL}$ of $10 \%$ of hydrochloric acid, then transferred into a $50 \mathrm{~mL}$ of calibrated flask and diluted to volume with $10 \%$ of hydrochloric acid. $5 \mathrm{~mL}$ of $10 \%$ citric acid was added to mask the nickel and cobalt. The palladium content was analyzed according to general procedure. The recovery test of palladium by adding $1.0 \mu \mathrm{g}$ of palladium in sample was carried out, and a standard method using flame atomic absorption spectrometry as literature ${ }^{19}$ was also used as reference method. The results are shown in Table 3 too.

\section{Conclusion}

A comparison of the proposed methods with other spectrophotometric methods (Table 4) shows the QADEAB is one of the most sensitive, selective and convenient spectrophotometric reagents for palladium.

Acknowledgement. This work was supported by the National Natural Science Foundation of China (20471051) and the Key Natural Science Foundation of Yunnan Province (2005K021).

\section{References}

1. Patrick, G.; Michel, P. Platinum. Met. Rev. 2003, 47, 60-72.
2. Caroli, S.; Alimonti, A.; Petrucci, F.; Bocca, B.; Krachler, M. Spectrochim. Acta B 2001, 56, 1241-124.

3. Zeng, Y. E.; Zhang, H. S.; Chen, Z. H. Handbook of Modern Chemical Reagents, The Forth Fascicule, Chromogenic Agent of Inoganic Ion, 1st ed: Chemical Industry Press: Beijing, P. R. China, 1989.

4. Yang, H. Q.; Zhang, G.; Zhang, L. L.; Liu, G. Q.; Zhang, X. H. Talanta 1996, 43, 747-753.

5. Murthy, G. V. R.; Reddy, T. S. Talanta 1992, 39, 697-701.

6. Gao, J. H.; Peng, B.; Fan, H. Y.; Kang, J. W.; Wang, X. D. Talanta 1997, 44, 837-842.

7. Mori, I.; Kawakatsu, T.; Fujita, Y.; Matsuo, T. Talanta 1999, 48, 1039-1044.

8. Ma, D. L.; Cui, F. L.; Xia, D. S.; Wang, L. L. Anal. Lett. 2002, 35, 413-421.

9. Sarma, L. S.; Kumar, J. R.; Reddy, K. J.; Kumar, A. K.; Reddy, A. V. Anal. Sci. 2002, 18, 1257-1261.

10. Gholivand, M. B.; Nozari, N. Talanta 2000, 52, 1055-1060.

11. Reddy, B. K.; Reddy, K. J.; Kumar, J. R.; Kumar, A. K.; Reddy, A. V. Anal. Sci. 2004, 20, 925-930.

12. Maria, B.; Katarzyna, P. Chem. Anal. 2003, 48, 87-95.

13. Hu, Q. F.; Yang, G. Y.; Yin, J. Y. J. Environ. Monit. 2002, 4, 956959.

14. Yang, G. Y.; Hu, Q. F.; Huang, Z. J.; Yin, J. Y. Anal. Sci. 2003, 19, 299-302.

15. Yang, G. Y.; Huang, Z. J.; Hu, Q. F.; Yin, J. Y. Talanta 2002, 58, 511-515.

16. Hu, Q. F.; Yang, G. Y.; Tang, D. Y.; Yin, J. Y. Chinese J. Anal. Chem. 2002, 30, 699-701.

17. Wang, L.; Yang, G. Y.; Hu, Q. F.; Yin, J. Y. Chem. Anal. 2003, 48, 767-773.

18. Analysis Method of Water and Wastewater, 3rd ed.; Chinese Environment Protection Agency, Ed.; Environmental Science Press: Biejing, P. R. China, 1989; pp 465-458.

19. Dong, S. A.; Chen, J.; Wu, R. L. Analysis Methods of Precious Metals, 1st ed.; Chinese Science Press: Beijing, P. R. China, 1995; pp 263-268. 